\title{
GEO ELECTRIC STUDY IN HYDROGEOLOGY ACCORDING TO THE AXIS HASSI NAGA - HASSI KHEBI OF TINDOUF (SOUTHWESTERN ALGERIA)
}

\author{
I. Zeroual ${ }^{1,2 *}$, K. Hami $^{1}$, A. Talhi ${ }^{1}$, A. Touhami ${ }^{1}$ \\ ${ }^{1}$ Department of Earth Science and the Universe, \\ University Centre Ali KAFI, Tindouf, 37000, ALGERIA \\ ${ }^{2}$ Laboratoire Géoressources et Risques Naturels (GEOREN), \\ Université d'Oran2, \\ BP: 1510, Oran, 31000, ALGERIA \\ *e-mail: zeroual_ib@yahoo.fr
}

The hydrogeological environment of the Saharan North East region of Tindouf is of utmost interest, particularly in agriculture. In fact, exploitation and exploration processes must be analysed to ensure sufficient water production. This study demonstrates the value of spatial processing and exploitation of geoelectric and geological data in the study area and facilitates interpretation. The results of the electrical survey and the spatial analysis of the data allowed us to design a complete model that met the needs of hydrogeology. The applied methodology consists in breaking down our subject into three (3) classes of entities: geomatics, geophysics and hydrogeology. Synthetic mapping based on continuity is the result of studying two sites (Hassi Naga and Hassi Khebi) for geological analysis. Knowing that the electrical resistivity is between 0 and $3000 \mathrm{Ohm}$-meter, we were able to construct thematic maps showing the spatial distribution of the facies and the probable positions of the boreholes. The study provided with a geo-spatial model highlighting the impact of measurements in hydrogeology of the area considered that was called SIHE (Information System for Environmental Hydrogeology).

Keywords: cartography, electrical resistivity, spatial processing, Tindouf.

\section{INTRODUCTION}

The use of the electrical method for the recognition of the subsoil is of great importance due to great variability of the resistivity of the components of the subsoil and its ease of implementation. The chosen arrangement is of the pole-pole type: a 
current electrode and a potential electrode are rejected to infinity. This configuration makes it possible to simplify the calculation of the apparent resistivity and to have a depth of recognition approximately equal to the distance separating the two remaining electrodes. In this study, the analysis of the electrical resistivity for groundwater resource recognition is applied to the Hassi Naga and Hassi Khebi area, located in the north-eastern part of the Tindouf basin (SW Algerian). Taking into account all the existing studies and the confrontation with the results of geophysics, we used the inverse process analysis. By measuring the resistivity of the layers, from which the lithology and the structure of the region are determined, we defined the aquifer levels, geometry and thickness [1].

In the field of cartography, cognitive mapping and spatial processing tools are paramount for studying the surface of the earth. The data are indispensable for any surveillance, photographic analysis and morphological modelling, whatever the scale. The new solutions are attractive, fast, and usable in any type of morphological configuration and provide easily integrable data in Geographical Information Systems (GIS), at resolutions ranging from hundreds of meters to centimetres [2], [3]. In several fields, the interest in spatial processing plays a central and fundamental role in the dissemination and communication of metadata as well as the visualization and implementation of the management processes using thematic maps. Water and energy are intimately associated with the energy process [4]. The amplifications by the international energy trade and studies show that international incarnated water flows averaged $6298 \mathrm{Mm} 3$ yr-1 from 1992 to 2010, which represented $10 \%$ of the water used for energy production, including oil, coal, gas and electricity production [4], [5].
On the other hand, models of the spatial distribution of wind speed and wind energy that were used to analyse the density were developed using the spatial interpolation method based on the genealogical measurement results and presented in cartographic form with a resolution of $1 \times 1 \mathrm{~km}$ [4], [6].

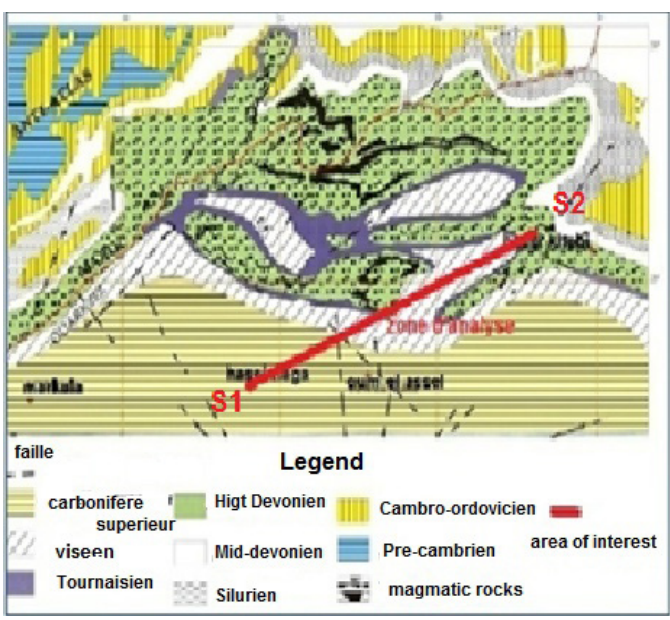

Fig. 1. Geological map of the North East zone of Tindouf [7], study area Hassi Naga (S1) Hassi Khebi (S2).

Spatial tools for geology and the hydrogeological environment are integrated with geophysical measurements in order to establish the exploration cognition of aquifers. In the present research, we insist on the contribution of topography, photogrammetry and GIS to develop thematic maps and synthesis maps. The geology of the study area is defined on the following map (Fig. 1). The syncline of Tindouf, better known in literature as Tindouf basin, whose surface is about $200000 \mathrm{~km}^{2}$, is the residue of a basin connecting the West - West Craton to the south, with the Mediterranean Sillon to the North. The Tindouf syncline, whose axis is west-east, is asymmetrical: in fact, the southern flank is represented by a monoclinal dipping gently towards the north $\left(1^{\circ}-5^{\circ}\right)$, while the north flank is narrower and is affected by many secondary folds. 
On the southern flank of the syncline, there are Paleozoic deposits ranging from Cambrian to Upper Carboniferous overlain in an unconformable way by the Hamadian Tertiary - Quaternary continental deposits. The electrical profiles, carried out along toposéquences and lithosequences previously identified, make it possible to establish a parallelism between the anomalies of resistivity and the different units of grounds; this on a very large scale.

On the Precambrian basement series, there is the formation of the Cambro-Ordo- vician, consisting of conglomeratic sandstones at the base, compact quartz sandstones and coarse-grained sandstones with a thickness of 40 to $70 \mathrm{~m}$. The Paleozoic formations are covered by Tertiary and Quaternary deposits of Hamada, consisting of whitish to greenish-grey argillaceous sandstones with conglomerates at the base, and a limestone dolomitic limestone slab with flint beds at the top. Its thickness can reach $80 \mathrm{~m}$. The study area concerns the north east of Tindouf with a surface coverage of $20000 \mathrm{~km}^{2}$.

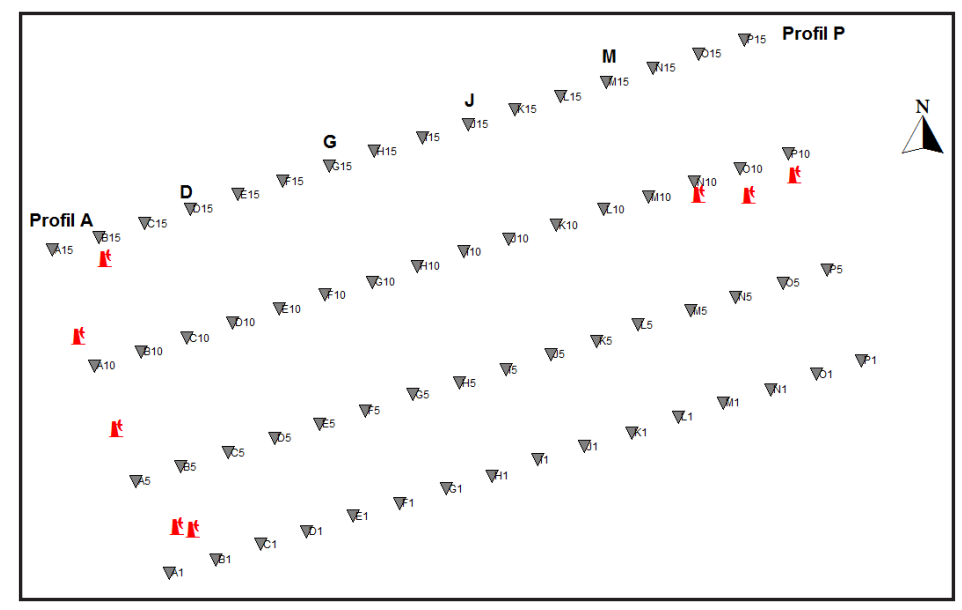

Fig. 2. Hassi Naga site profiles.

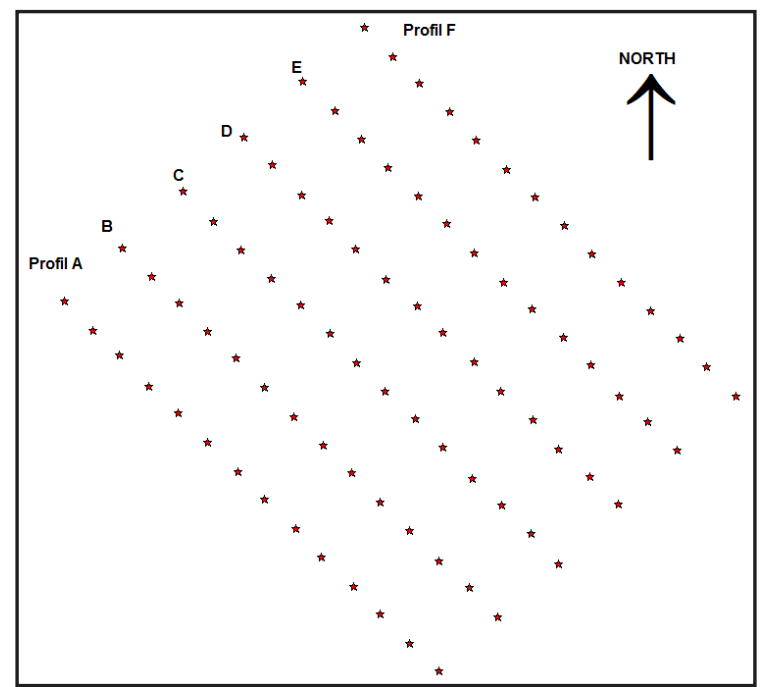

Fig. 3. Hassi Khebi site profiles. 
The inverse electrical problem is complex due to its non-linearity [8]: the measured apparent resistivities do not depend linearly on the real resistivities of the computational cells. It is then necessary to perform a parametric study to determine the factors that have a significant weight in the measurement. The least-squares inversion

\subsection{Observation Model}

The electrical method consists in injecting a continuous electric current into the ground using two stainless steel electrodes and measuring the potential deference created between the terminals of two other copper electrodes. The set constitutes a quadrupole as it is in Fig. 3, an ammeter is used to measure the electrical current and a voltmeter to measure the potential difference (Fig. 3):

The idea is to move the four AMNB electrodes together and, thus, make profiles and resistivity cards. There is a variety scheme is a classic but convenient concept for reversing 3-D resistivities. With a sufficient amount of data, the reconstruction of the distribution of true resistivity is possible. In order to overcome the problems of resolution and inversion of linear and nonlinear systems, the mapping approach of spatial distributions is used.

of devices but the quadrupole remains the most widespread. The power source is usually $90 \mathrm{v}$ batteries, more rarely a gasoline generator with a rectifier or a car battery, the new devices work with ten (10) batteries in series. This method makes it possible to measure the potential difference $\Delta \mathrm{V}$ and the electric current I injected and recovered in the subsoil. This leaves for us the calculation of the resistivity in the considered medium with two poles $\mathrm{A}$ and $\mathrm{B}$, the combined action of $\mathrm{A}$ and $\mathrm{B}$ will give:

\section{Potential at a point $M$ and $N$ :}

$V_{M}=\rho I / 2 \pi(1 / A M-1 / B M) ; V_{N}=\rho I / 2 \pi(1 / A N-1 / B N)$.

\section{Potential difference between $\mathrm{M}$ and $\mathrm{N}$ :}

$\Delta V=V_{M}-V_{N}=\rho I / 2 \pi(1 / A M-1 / B M-1 / A N+1 / B N)$.

From where:

$\rho=(k \cdot d V) / I$

where

$k=\pi \cdot(A M \cdot A N) / M N$. 


\section{Resistivity in ohm-meter is calculated by:}

$\rho_{a}=(k \cdot \Delta V) / I_{A B}$,

where

$k$ - the geometrical factor that depends only on the relation of the electrodes and is expressed by (4);

$\Delta V$ - the potential difference across $\mathrm{MN}$ electrodes;

$I_{A B}$ - intensity of the electric current circulating in the circuit AB.

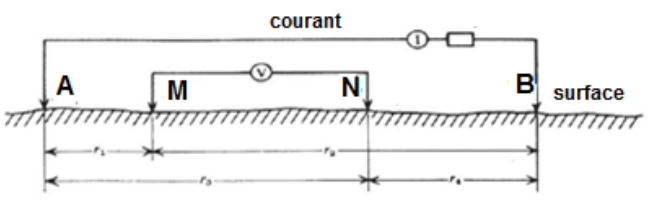

Fig. 3. Scheme of Schlumberger chosen for prospecting sites.

All conventional methods of interpreting electrical soundings are based on the two basic assumptions about vertical variation and horizontal variation. It is essential that both of these conditions are fulfilled for an electrical survey to yield to correct interpretation. Parametric soundings are essential; they are placed near a mechanical drilling or on outcrops. They make it possible to get an idea of the resistivity in a region and they also make it possible to fix the line lengths effective for the execution of the second phase.

Thanks to the resistivity maps established during the second phase that the geophysicist can place the electrical soundings of the third phase in an optimal way, that is to say, in the zones of interest, the resistivity varies less possible horizontally [9], [10].

Tables 1 and 2 present a scale for calibrating geo-electrical measurements in the areas in question.

Table 1. Resistivity Scale Adopted at Hassi Naga

\begin{tabular}{|c|c|c|c|}
\hline Formation & \multicolumn{2}{|r|}{ Age } & Résistivité Ohm-m \\
\hline Sandstone limestone & \multirow{4}{*}{\multicolumn{2}{|c|}{ Neogene Hamada }} & $211-1070$ \\
\hline Sandstone - clay sand & & & $53-137$ \\
\hline Sandy clay & & & $30-50$ \\
\hline Gypsum intercalation clays & & & $9-28$ \\
\hline Clayey sandstone & \multirow{4}{*}{ Paleozoic } & \multirow{2}{*}{$\begin{array}{c}\text { Upper } \\
\text { Carboniferous }\end{array}$} & $77-102$ \\
\hline Silty clay with sandstone & & & $30-71$ \\
\hline $\begin{array}{l}\text { Clay with intercalation } \\
\text { of gypsum }\end{array}$ & & \multirow{2}{*}{ Higher Viseen } & $8-28$ \\
\hline $\begin{array}{l}\text { Limestone and } \\
\text { anhydrite }\end{array}$ & & & $230-3622$ \\
\hline
\end{tabular}


Table 2. Summary Table of Lithology at Hassi Khebi

\begin{tabular}{|c|c|c|c|}
\hline Lithology & Age & Resistivity adopted (ohm-m) & Observations \\
\hline $\begin{array}{l}\text { More or less silicified } \\
\text { limestone Neogene }\end{array}$ & $\begin{array}{c}\text { Tertiary } \\
\text { Continental or TC) }\end{array}$ & $150-500$ & Aquifer, low flow \\
\hline $\begin{array}{l}\text { Siltstones, quartzites and } \\
\text { argillites }\end{array}$ & Carboniferous & $200-400$ & Aquifer very unlikely \\
\hline $\begin{array}{l}\text { Argillites, limestones } \\
\text { containing pyrite (FeS2), } \\
\text { siltstones and quartzose } \\
\text { sandstones, dolerites }\end{array}$ & Upper Devonian & $20-40,50-100$ et $>120$ & $\begin{array}{l}\text { Probable aquifer if the roof } \\
\text { of the formation is close to } \\
\text { the ground }\end{array}$ \\
\hline $\begin{array}{l}\text { Argillites, past siltstone } \\
\text { limestones, argilites and } \\
\text { massive pyritized marls }\end{array}$ & Middle Devonian & $>500$ & No aquifer \\
\hline $\begin{array}{l}\text { Clay, fine quartzose } \\
\text { sandstone, compact, clay } \\
\text { limestone }\end{array}$ & Lower Devonian & $30-150$ & $\begin{array}{l}\text { Aquifer to be collected by } \\
\text { shallow drilling } \\
(150-300 \mathrm{~m}) .\end{array}$ \\
\hline $\begin{array}{l}\text { Argilites and marls } \\
\text { massive pyritized Facies } \\
\text { dominated clay. Schists } \\
\text { and sandstones of "Bani" }\end{array}$ & $\begin{array}{c}\text { Silurian: } \\
\text { Ordovician } \\
\text { Gothlandian }\end{array}$ & 50 à 90 & $\begin{array}{l}\text { Aquifer likely when these } \\
\text { formations are close to the } \\
\text { ground }\end{array}$ \\
\hline Quartzitic and Quartzite & $\begin{array}{l}\text { Cambro - } \\
\text { Ordovician }\end{array}$ & $>1000$ & No aquifer \\
\hline
\end{tabular}

These tables will allow us to set up the spatial analysis function and to create a syn- thetic cartography on the spatial distribution of electrical resistivity.

\subsection{Modelling and Spatial Analysis in Geology}

A cognitive map provides a simple visual communication medium for humans analysing a complex system that can be processed through brainstorming phases. These maps have been used in several fields such as biology, ecology and the environment in general [2], [3], [5]. In the present research, cognitive mapping is based on spatially referenced information systems that highlight electrical resistivity. The following steps [11], [12] illustrate an approach based on computer science:

- The brain-ware phase: a conceptual reflection on the model;

- The software phase: a logical transformation of the model;
- The hardware phase: a physical implementation of the model.

Supporting and integrating data from geophysical exploration and groundwater behaviour, and integrating environmental data with GIS require the development of a conceptual data model (CDM). This is the result of the analysis of the existing data and the surveys with the future developments of the GIS [13]. It represents in a synoptic way all the data and the links that exist among them. The MCD questions take up the problems of treatment.

It involves bringing into play many elements for the generation of simulation models; this is possible thanks to the following 
concepts:

- The topographic surface;

- The attributes and the physicochemical properties of the places;

- The evolution time in the form of intervals, iterations, or recursive constructions;

- The inference engine that is generated by deterministic or stochastic transformation rules.

It is therefore easy to understand the considerable contribution the geological spatial analysis makes to thematic and simulation mapping by enabling multiple structures at once and facilitating quick visualization of results. The groundwater can be considered a localized area delimited topographically where space operations are carried out. Thus, the classical repertoire of three-dimensional coordinates becomes a table supplemented by indicators of this hydrogeological environment.

We present a general approach for the assimilation of different aspects of management and exploitation of tablecloths. The main objectives of this specification are as follows:

- Integration of different natural and artificial contexts into the same database;

- Homogenization of the local geographic database;

- Production of a data model (maps) without redundancy;

- Standardization of spatial analysis and decision-making;

- Assistance with maintenance and prevention;

- Prediction capability (periodic synthesis of dynamic parameters).

The process begins with the assimilation of the following territorial contexts:

- The geology of the region;

- The topography;

- The agglomeration.

Each context is represented by a digi- tized layer of the map attached to a class of the database. Then we integrate the hydric aspects where each unit (or hydrogeological subunit) will be characterised according to several contexts, namely:

- Hydrogeology;

- Hydrography and hydrology;

- Hydrodynamics.

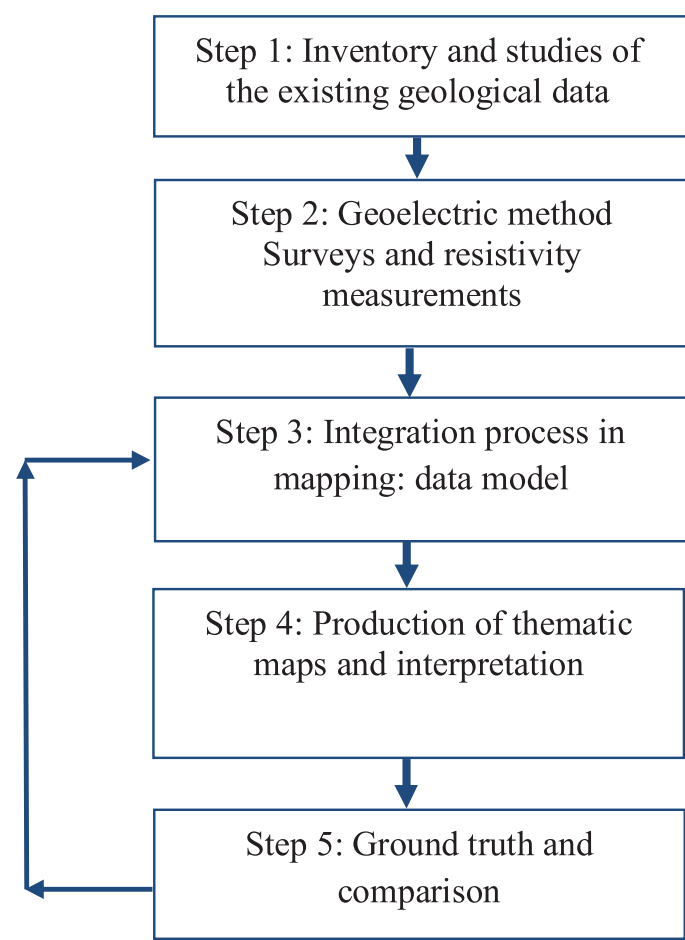

Fig. 4. Summary of different stages of the study.

The analysis and synthesis of the data involve periodic sampling measurements on aquifers, as well as hydrographic and hydrodynamic elements according to the following groups of parameters:

- hydrochemistry, physicochemical, toxic substances, undesirable substances, microbiological parameters and the total rate of pesticides;

- history of flows / consumption of the hydrodynamic elements;

- parameters for calculating vulnerability to pollution according to one or more methods. 
A quality assurance program based on the flowchart in Fig. 5 provides alternatives for inventory and analysis. This brings us back to developing a data model that will be appended to different layers of the hydrogeological database (Fig. 5). In this model, the map class is the subject of this article.

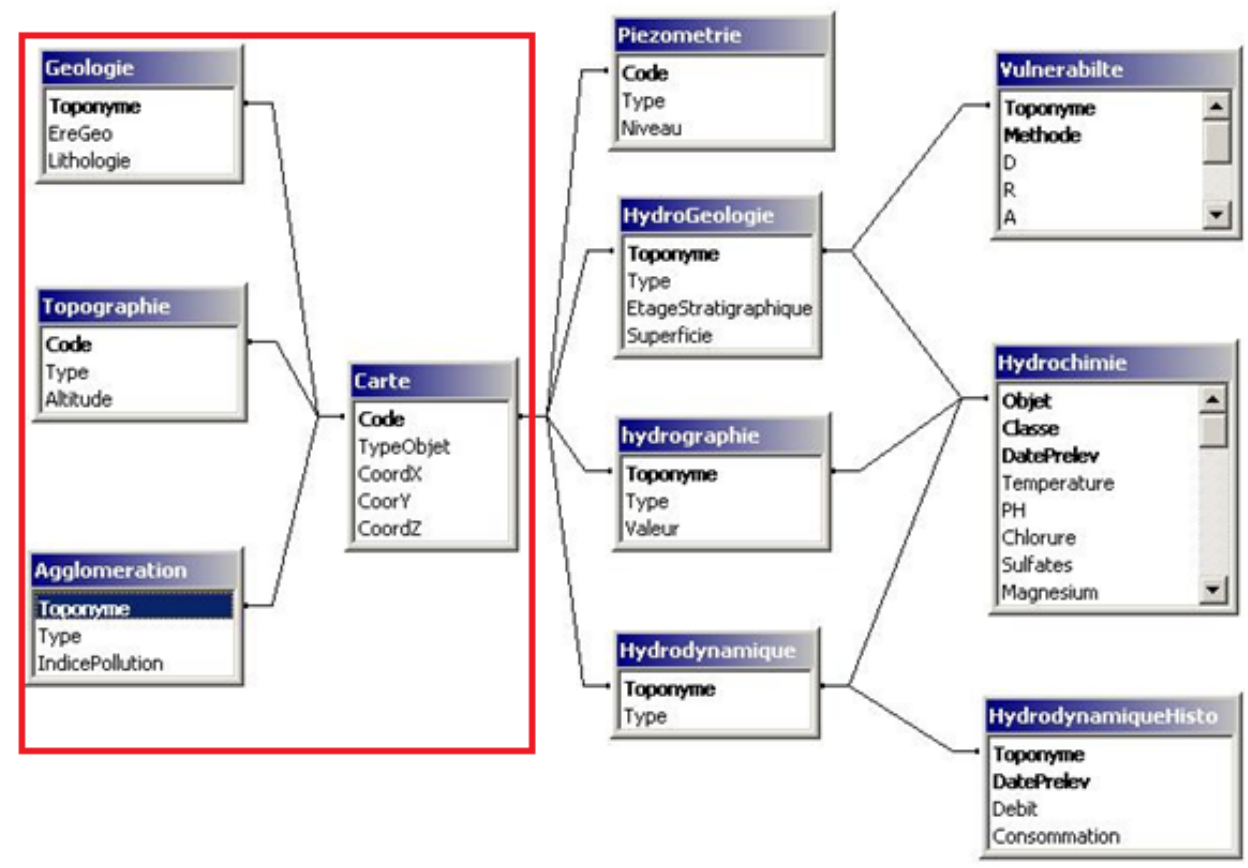

Fig. 5. Logic model (SIHE) of data and focus of study in red.

\section{TREATMENTS FOR TWO SITES: HASSI KHEBI AND HASSI NAGA}

The treatments are based on an information system for environmental hydrogeology (SIHE - Fig. 5), which poses a double problem related to the inventory of different information and its structuring in the form of diagrams. According to Ruas [14], this inventory step requires taking into account a transfer model, adapting the diagram of the SIHE and looking for equivalence between the technical options and the card elements. Despite knowing that engineering in hydrogeology is expensive, it remains crucial for the success of hydro-environmental projects. In this perspective, the treatments present orthogonal projections of interpretive geoelectric sections and maps of appa- rent resistivities. All profiles are oriented South-South-East / North-North-West with similarities in their monotonous look and in the thicknesses of the geological formations. Recorded resistivity is almost similar. The measurement campaigns relate to two sites separated by a distance of 200 kilometres: Hassi Naga (S1) and Hassi Khebi (S2). There are 16 and 6 profiles, respectively, for both sites S1 and S2.

The dome-shaped structure of Hassi Khebi deserves to be explored in more detail. Secondary complications may exist in this major structure. For example, near the curbs, the tanks can be emptied. Moreover, the village of Hassi Khebi, on its cur- 
rent location (rocky plateau, total absence of vegetation), can logically develop a serious and viable activity. It would be a judi- cious parallel thinking about a partial relocation of the population in the plain of Oued Khebi $20 \mathrm{~km}$ away from the village.

Table 3. Summary of Hassi Naga Profiles

\begin{tabular}{|c|c|c|c|c|}
\hline $\begin{array}{l}N^{\circ} . \\
\text { Profile }\end{array}$ & $\begin{array}{l}\text { Layer } 1 \\
\text { C1 }\end{array}$ & $\begin{array}{l}\text { Layer } 2 \\
\text { C2 }\end{array}$ & $\begin{array}{l}\text { Layer } 3 \\
\text { C3 }\end{array}$ & Comments \\
\hline A & $\begin{array}{l}118-571 \text { Ohm-m } \\
25-77 \text { Ohm-m }\end{array}$ & 8-62 Ohm-m & $\begin{array}{l}195-1350 \\
\text { Ohm-m }\end{array}$ & $\begin{array}{l}\text { C1: Neogenous } \\
\text { C2: Upper carboniferous } \\
\text { C3: Lower carboniferous. }\end{array}$ \\
\hline B & 31-116 Ohm-m & 18-52 Ohm-m / 70-102 Ohm-m & $\begin{array}{l}190 \text { à } 1342 \\
\text { Ohm-m. }\end{array}$ & $\begin{array}{l}\text { C1: Neogenous } \\
\text { C2: Upper carboniferous } \\
\text { C3: Carbonifère inférieur. }\end{array}$ \\
\hline C-D & $\geq 200 \mathrm{Ohm}-\mathrm{m}$ & 10-57 Ohm-m & $\begin{array}{l}234-1453 \\
\text { Ohm-m }\end{array}$ & $\begin{array}{l}\text { C1: Neogenous } \\
\text { C2: Upper carboniferous } \\
\text { C3: Lower carboniferous. }\end{array}$ \\
\hline E-F & 20-200 Ohm-m & 15-50/65-73 Ohm-m. & $\begin{array}{l}205 \text { et } 1216 \\
\text { Ohm-m }\end{array}$ & $\begin{array}{l}\text { C1: Neogenous } \\
\text { C2: Upper carboniferous } \\
\text { C3: Lower carboniferous. }\end{array}$ \\
\hline G-H & 21-90 Ohm-m & 11 à $41 / 52$ à 57 Ohm-m & $\begin{array}{l}\geq 229 \\
\text { Ohm-m }\end{array}$ & $\begin{array}{l}\text { C1: Neogenous } \\
\text { C2: Upper carboniferous } \\
\text { C3: Lower carboniferous. }\end{array}$ \\
\hline $\mathrm{I}-\mathrm{J}$ & $\geq 129$ Ohm-m & $<100$ Ohm-m & $\begin{array}{l}<50 \\
\text { Ohm-m }\end{array}$ & $\begin{array}{l}\text { C1: Neogenous } \\
\text { C2: Upper carboniferous } \\
\text { C3: Lower carboniferous. }\end{array}$ \\
\hline $\mathrm{K}-\mathrm{L}$ & 77-115 Ohm-m & $<50$ Ohm-m & $\begin{array}{l}\geq 350 \\
\text { Ohm-m }\end{array}$ & $\begin{array}{l}\text { C1: Neogenous } \\
\text { C2: Upper carboniferous } \\
\text { C3: Lower carboniferous. }\end{array}$ \\
\hline $\mathrm{M}-\mathrm{N}$ & $\begin{array}{l}<43 / 58 \text { à } 265 \\
\text { Ohm-m }\end{array}$ & $<50$ Ohm-m/ $\geq 400$ Ohm-m & $\begin{array}{l}\geq 350 \\
\text { Ohm-m }\end{array}$ & $\begin{array}{l}\text { C1: Neogenous } \\
\text { C2: Upper carboniferous } \\
\text { C3: Lower carboniferous. }\end{array}$ \\
\hline $\mathrm{O}-\mathrm{P}$ & $<30 / \geq 45$ Ohm-m & $10-46$ Ohm-m & $\begin{array}{l}\geq 200 \\
\text { Ohm-m }\end{array}$ & $\begin{array}{l}\text { C1: Neogenous } \\
\text { C2: Upper carboniferous } \\
\text { C3: Lower carboniferous. }\end{array}$ \\
\hline
\end{tabular}

All the data collected are related to the spatial and temporal contexts. It should be noted that all samples must be structured and stored (archived). Thus, we equip our GIS with an effective tool for monitoring the evolution of the water table. This concept, called "object version", is widely used in software engineering [15]. The process of exploitation of the water table is completed (after structuring and data acquisition) and more complex tasks (integration of data, interpolation of measurements taken, homogenization, etc.) are carried out. These synthesis tasks are provided by tools developed and integrated incrementally in the GIS. The current prototype can be enriched by applying it on several real cases. 
Scientific interpretation and visualization bring a new configuration for exploratory analytical cognition of groundwater. The generalization and aggregation of cognitive information allows for a better perception in the context of exploration. The study of the integration of GIS as a decision-making support tool in hydrogeology training and the difficulties that accompany it called for a multidisciplinary approach. It was organised around the following themes:

1. A geometric theme around scientific visualization to predict levels of abstraction;

2. A cognitive approach, which allowed studying the way of thinking of users in cartography, facing the solution of spatial problems using GIS;

3. A didactic dimension, which allowed integrating the expert approaches used in the strategies of resolution of the distribution of resistivity through the formations;

4. Based on cognitive and didactic knowledge, innovative training devices in line with the demands of the professional world.

The analysis of the data from the observations was guided theoretically, by the framework of visual-cognitive mechanisms involved in reasoning, and methodologically by the qualitative and quantitative treatments of the geophysical process protocols. This allowed us to identify components of the reasoning processes involved in the realization and perception of a digital mapping activity. The multidisciplinary approach also facilitated the match between training and profession, combining skills in GIS methods and technologies, to the needs of a specific professional sector (geological sciences). The sections and the geophysical profiles allowed us to build levels of analysis by aggregation of the resistivities of levels R1 to R8. Figure 6 shows level R1.

In this study, we approach a multiscale design using geomatic tools. The GIS approach is launched to validate the structuring model; the following maps provide an overview of the timeline of reassignment operations and the use of profiles. The functions applied take into account the location and parameterization of each variable. Relation 6 summarises the elaborated treatments.

$G=f(x, y, z, \alpha, \beta, \theta)$,

where

$(x, y, z)$ - represent the location factors (Cartesian coordinates, DTM and DSM);

$(\alpha, \beta, \theta)-$ thematic values related to the application (type, nature, identification).

Univariate and multivalue processing of location and geoelectric parameters reflect repeated effects of classes. The histograms in Fig. 6 show the predominance of these classes. The analysis of the maps shows a sudden geoelectric change, which may suppose a fault or deformation at this level (figure arrows 6C and 6D).

The formulation of the geoelectric analysis is based on a reciprocal function of type:

$z=F(x, y, \alpha, \beta, \theta)$.

The dissimilarities observed between the maps of apparent resistivity reveal the transition zones between homogeneous soil units and thus specify the notion of progressive limit in space. 


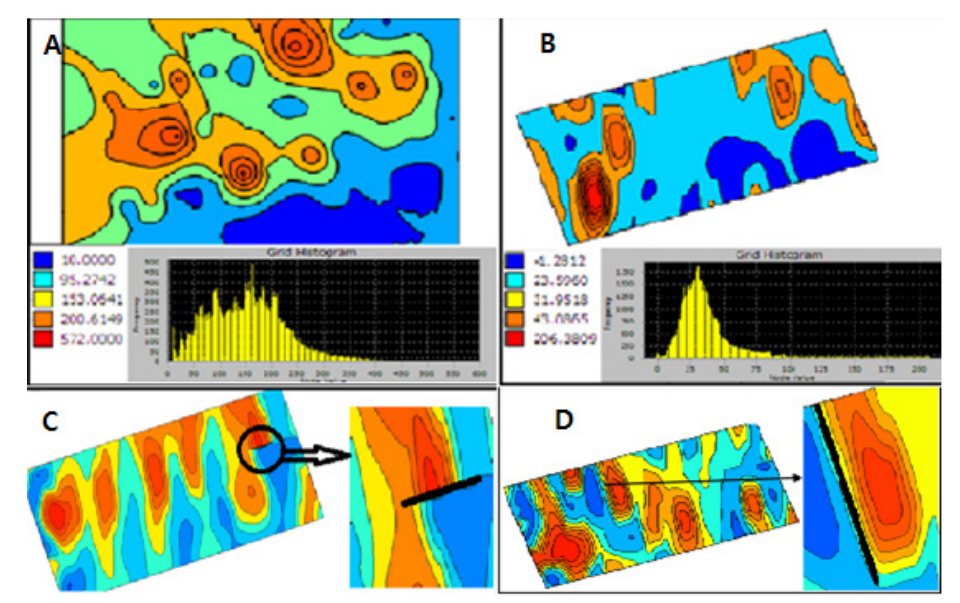

Fig. 6. Thematic maps of electrical resistivity (A and B) and geoelectric discontinuity observed in $\mathrm{C}$ and $\mathrm{D}$ (Hassi Naga).

The spatial representation of the thickness of the geological layers and its histogram highlight structural aspects that can be caused by deep tectonic deformations (Fig. 7A). Piezometry and its histogram in the Hassi Khebi area imply spatial compatibility with the representation of resistivity; this visualization makes it possible to generate a thematic function (thickness-resistivity and piezometry).

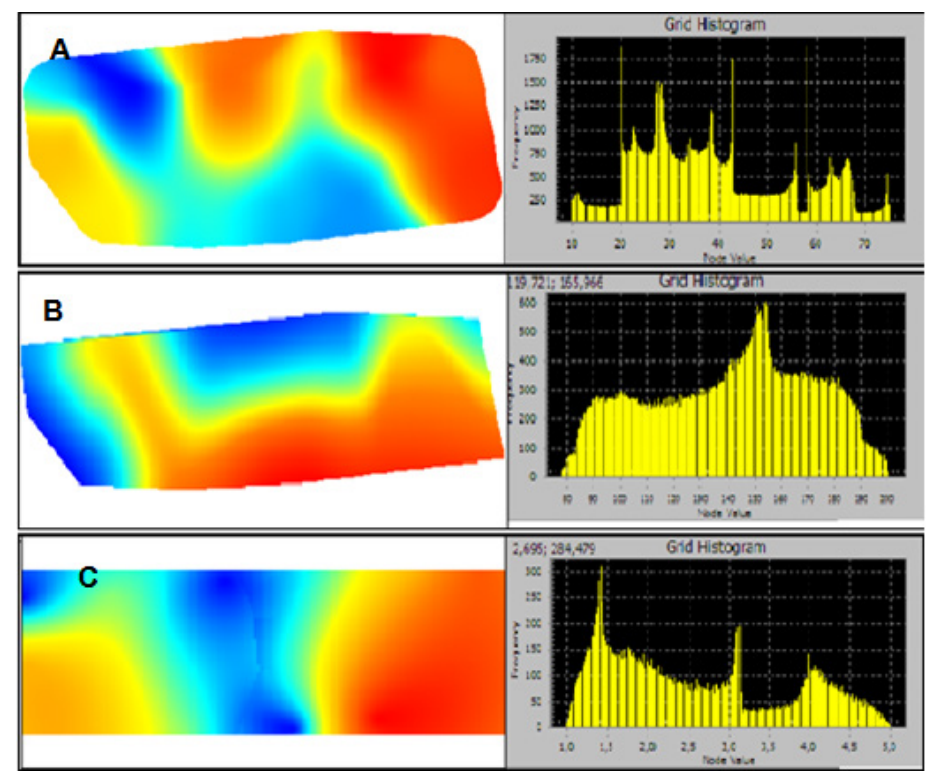

Fig. 7. Themes on thickness A, piezometry B and resistivity C (Hassi Khebi area); the histograms show the impact of the resistivity on thicknesses and piezometry.

The spatial visualization of the flows of the six (6) existing boreholes allowed us to compare the spatial distribution with the existing geological factors. A proposal for drilling is given in Table 4. The spatial representation of existing borehole flows is in line with the geological features of Fig. 8. A geological correlation of surface type is 
therefore desirable for a complete geological survey (Fig. 9). The direction S1S2 in Fig. 1 defines the interpolation zone to analyse the layers relating to the resistivities of layers $\mathrm{C} 1, \mathrm{C} 2$ and $\mathrm{C} 3$.

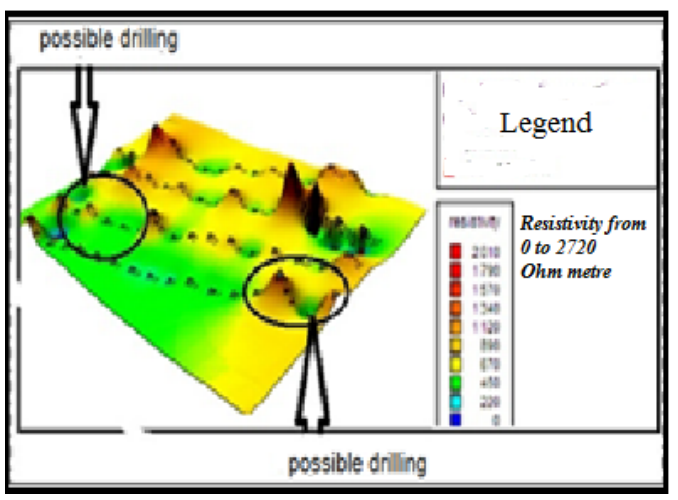

Fig. 8. Resistivity provides two possible drill sites.

A drilling proposal is being established in the Hassi Khebi area. To complete Table 4 of the proposals, it is strongly recommended a geophysical prospection by electrical soundings in the north sector of Hassi Khebi on a strip parallel to the reliefs of Adhim Filou. These profiles would be perpendicular to this line. The depth of investigation should be of the order of 400 to 500 $\mathrm{m}(\mathrm{AB}=3000 \mathrm{~m})[16]$.

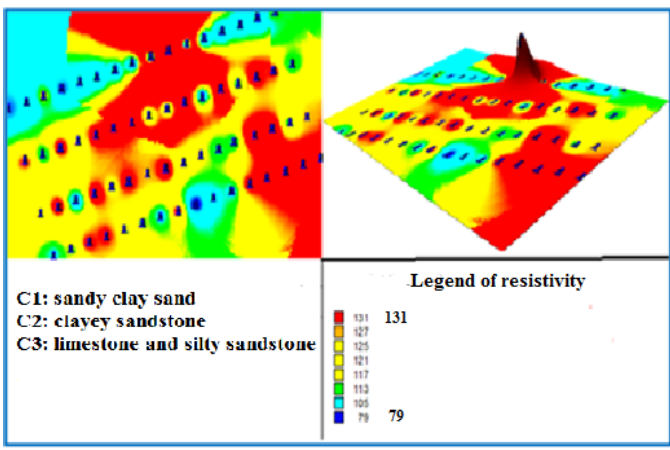

Fig. 9. Aggregated function to obtain the elements of layers $\mathrm{C} 1, \mathrm{C} 2$ and $\mathrm{C} 3$.

Table 4. A Drilling Proposal in the Hassi Khebi Area

\begin{tabular}{|l|c|c|c|c|}
\hline Cup & Depth(meter) & Training (s) to capture & X & Y \\
\hline A & 100 & T C and carboniferous & 252.850 & 3241.459 \\
\hline A & 150 & T C, carboniferous and upper Devonian & 262.625 & 3231.375 \\
\hline B & 150 & T C and upper Devonian & 264.082 & 3235.596 \\
\hline B & 150 & T C and upper Devonian & 265.477 & 3234.121 \\
\hline C & 200 & T C and lower Devonian & 262.887 & 3242.618 \\
\hline C & 200 & T C and upper Devonian & 269.869 & 3235.388 \\
\hline D & 150 & T C and Lower Devonian & 268.510 & 3242.588 \\
\hline E & 200 & T C and lower Devonian & 271.436 & 3245.350 \\
\hline E & 200 & T C and lower Devonian & 272.785 & 3243.925 \\
\hline F & 150 & T C and upper Devonian & 264.561 & 3258.178 \\
\hline F & 300 & T C, Middle Devonian, and lower Devonian & 274.336 & 3248.095 \\
\hline F & 300 & T and lower Devonian & 278.432 & 3243.865 \\
\hline
\end{tabular}




\section{CONCLUSION}

The execution of the exploration work is based on the methodology of the threedimensional geological and geophysical model of various hydrogeological indices. These are recognised in exploited aquifers such as Hassi Naga and Hassi Khebi; they will discover new hidden mineralized boreholes and, thus, ensure the economic development of the north eastern region of Tindouf. The proposed model can be used for bettering the field management, prioritizing actions for monitoring groundwater quality and remediation of polluted sites. The integration of other geophysical methods, taking into account all the geological parameters, and the geomatic data available in the region in hydrogeological material, can help us develop and modernise the proposed analysis model towards good exploitation and integrated management of water resources. The SIHE model "Information System in Environmental Hydrogeology" can be extended for the support of structural elements at the level of geological and hydrogeological units. In a multidisciplinary vision, the preservation and protection of aquifers will be indexed to the land planning model. By knowing the genesis of quaternary deposits of the study sites, we can infer the type of deposit and their sedimentary structures that are specific to them from the geometry and spatial relationships of the reflectors visible on the geoelectric profiles [17].

\section{REFERENCES}

1. Teibe I., Bendere R., \& Arina, D. (2013). Latvian Waste Management Modelling in View of Environmental Impact Reduction. Latvian Journal of Physics and Technical Science, 50 (6), 36-47. DOI: 10.2478/ lpts2013-0039

2. Axelrod, R. M. (1976). Structure of decision: The cognitive maps of political elites. N.J.: Princeton.

3. Celik, F. D., Ozesmi, U., \& Akdogan, A. (2005). Participatory ecosystem management planning at Tuzla lake (Turkey) using fuzzy cognitive mapping. Eprintar Xiv:q-bio/0510015, 2005.

4. Zhang, J. C., Zhong, R., Zhao, P., Zhang, H. W., Wang, Y., \& Mao, G. Z. (2016). International Energy Trade Impacts on Water Resource Crises: An Embodied Water Flows Perspective. Environ. Res. Lett. 11, 074023.
5. Chauvin, L., Genest, D., Le Dorze, A., \& Loiseau, S. (2013). User centered cognitive maps. In Guillet, F., Pinaud, B., Venturini, G., and Zighed, D. A. (eds.), Advances in Knowledge Discovery and Management, volume 471 of Studies in Computational Intelligence (pp. 203 220). Springer.

6. Aniskevich, S., Bezrukovs, V., Zandovskis, U., \& Bezrukovs, D. (2017). Modelling the Spatial Distribution of Wind Energy Resources in Latvia. Latvian Journal of Physics and Technical Sciences, 54 (6), 10-20. DOI: 10.1515/Lpts-2017-0037

7. Dida, M., Bentaleb, A., \& Zeroual, I. (2017). Master's Memory. Digital Cartography and the Geoelectric Study of Hassi Khebbi Zone, 20-40. 
8. Panissod, C. (1997). Prospection electrique et electrostatique a faible profondeur a l'aide de systemes multipoles permettant la description directe des structures. In "3-D".

9. Chandrasekharan, H., Yada, B., Tomar, S., \& Sarma, P. (1994). Studies on Salinity and Water Content of Soils. Geoelectrical Approach. Journal of The Indian Society of Soil Science, 42 (3), 430-436.

10. Kalinski, R., \& Kelly, W. (1994). Electrical Resistivity Measurements for Evaluating Compacted-Soilliners. Geotech., 120 (2), 451-457.

11. Le Dorze, A., Duval, B., Garcia, L., Genest, D., Leray, P., \& Loiseau, S. (2013). Cartes cognitives probabilistes. Technical report, LERIA - Universited' Angers.

12. Sedki, K., \& Bonneau De Beaufort, L. (2012). Cognitive maps and Bayesian networks for knowledge representation and reasoning. In IEEE 24th ICTAI (pp.1035-104).
13. Laurini, R.,\&Milleret-Raffort,F.(1993). Les bases de données en géomatique. Edition HERMES- France.

14. Booch, G. (1992). Conception orientée objet \& applications. Edition Wesley.

15. Ruas, A., \& Sanders, L. (2015). Regards croisés sur la modélisation des dynamiques spatiales, Revue Internationale de Géomatique, 25 (3), 275-300.

16. Khelifa, H., Zeroual, I., Talhi, A., \& Djmila, A. (2017.). Contribution de la géomatique à l'interprétation géoélectrique du bassin de Hassi Naga (Sud-ouest Algérien). In International Congress on Energetic and Environmental Systems (IEES-2017), Djerba, Tunisia.

17. Gousmania, M., Gasmi, M., Mhamdi, A., Bouri, S., \& Ben Dhia, H. (2006). Prospection géoélectrique pour l'étude de l'aquifer thermal des calcaires récifaux, Hmeima-Boujabeur (centre ouest de la Tunisie). C.R. Geosciences, 338, 1219-1227. 